\title{
Evaluation of Total White Blood Cells and Cluster of Differentiation 4 Cells among Post-Menopausal Women in Elele, Nigeria
}

\author{
Benjamin Onyema Eledo1,2, Matthew Ugwu Igwe' ${ }^{1}$, Sylvester Chibueze Izah ${ }^{3}$ \\ ${ }^{1}$ Department of Medical Laboratory Science, Faculty of Health Sciences, Madonna University, Elele, Nigeria \\ ${ }^{2}$ Departments of Haematology and Blood Transfusion, Federal Medical Centre, Yenagoa, Bayelsa State, Nigeria \\ ${ }^{3}$ Department of Biological Sciences, Faculty of Science, Niger Delta University, Wilberforce Island, Bayelsa State, Nigeria \\ Email:chivestizah@gmail.com
}

How to cite this paper: Eledo, B.O., Igwe, M.U. and Izah, S.C. (2018) Evaluation of Total White Blood Cells and Cluster of Differentiation 4 Cells among Post- Menopausal Women in Elele, Nigeria. Modern Research in Inflammation, 7, 21-29. https://doi.org/10.4236/mri.2018.72003

Received: November 13, 2017

Accepted: May 8, 2018

Published: May 11, 2018

Copyright $\odot 2018$ by authors and Scientific Research Publishing Inc. This work is licensed under the Creative Commons Attribution International License (CC BY 4.0). http://creativecommons.org/licenses/by/4.0/

\begin{abstract}
This study investigated some immune system related parameters among post-menopausal women in Elele, River state, Nigeria. Forty-two individuals participated in this study and forty control subjects were established as well. Blood was collected from the participants, and CD4 cells and total white blood cells count were analyzed using standard procedures. Result showed that test subjects and control values were $5.46 \pm 1.64 \times 10^{9} / \mathrm{L}$ and $7.24 \pm 1.47 \times 10^{9} / \mathrm{L}$, respectively for total white blood cell and $1265.19 \pm 458.56 \mathrm{cells} / \mu \mathrm{l}$ and $2159.53 \pm 400.02$ cells $/ \mu$ respectively, for CD4 cells. There was significant difference $(\mathrm{P}<0.001)$ among the test subject and control for both parameters. The results in the test subjects for both parameters were significantly lower compared to the control. The decline in immune system related parameters among the test subjects may predispose them at risk of multiple infections and other associated health conditions.
\end{abstract}

\section{Keywords}

Ageing, CD4 Cells, Women Physiology, White Blood Cells

\section{Introduction}

Among women of reproductive age, several hormones such as follicle-stimulating hormone, luteinizing hormone, estradiol and progesterone play a significant role. For instance, AACC [1] reported that these hormones play an essential role in egg development and its release from the ovaries (ovulation) monthly. The hormones also play an essential role in the regulation of women monthly men- 
strual period and/or support the beginning of a pregnancy [1]. Probably due to ageing in women, the ability to produce estradiol or inhibin decreases and the follicle-stimulating hormone and luteinizing hormone can no longer be inhibited by estrogen's negative feedback mechanism [1] [2] [3]. The decline and inconsistency in cyclical production of estradiol and progesterone are some of the early signs of menopause [2] [3].

Menopause is the cessation of a woman menstrual period. This usually occurs when an adult woman has stopped mensuration for at least 12 calendar months and she can no longer get pregnant [1] [4]-[9]. Menopause can occur any time once a woman is in her late 40s to early 50s [1] [2], typically with the range of 48 - 55 years [9].

Menopause leads to several changes in the body of a woman. According to Lages et al. [10], Gavazzi and Krause [11], Eledo et al. [4], Pistilli et al. [12], Sivro et al. [13], it leads to defect on the immune system response and predisposes the body to multiple infections. According to Eledo et al. [4], transition from one physiological being to another could alter the blood parameters. For instance, Eledo et al. [14], Eledo [15] reported that habits such as smoking could alter haematological parameters. Igbeneghu and Odaibo [16] reported that disease condition such as malaria could lead to alteration in some blood parameters. Eledo et al. [17] reported that disease such as diabetes could affect haemostatic parameters. Eledo et al. [18], Papadopol et al. [19], Achie et al. [7] reported that health condition such as pregnancy could lead to defect in some haematological characteristics. Eledo et al. [20] reported that exercise could also lead to variation in haemostatic parameters.

Some important immune response measurable parameters are white blood cell and CD4 cells. CD4 cells have been widely used to measure ability of the body to fight infections. According to Cichocki [21], CD4 is a type I trans-membrane glycoprotein that is involved in the recognition of MHC class II/peptide complexes by the TCR heterodimers. The author further reported that CD4 is highly expressed on Thelper cells and at a lower level on monocytes and dendritic cells.

White blood cells are essential parameters used in measuring immune system response. Typically, white blood cells help the body to fight against infections resulting from pathogens such as bacteria, viruses and other endo and ecto-parasites. These cells are produced in the stem of the bone marrow and are composed of granulocytes (neutrophils, eosinophils, and basophils) and non-granulocytes (lymphocytes and monocytes). Each of these types of white blood cells carries out unique functions for the immune system.

Several studies have been conducted on the effects of menopause on some haematological parameters [4]. But information about its effect on CD4 cells appears scanty in literature. Therefore, this present study aimed at assessing the effects of menopause on some immune system related parameters among post-menopausal women in Elele, River state, Nigeria. 


\section{Materials and Methods}

\subsection{Study Area}

Elele is one of the communities in River state in the Niger Delta region of Nigeria. Typically, Rivers state shares boundary with other Niger Delta states such as Bayelsa, Delta, Imo, Abia. Some parts of the River state are close to the Atlantic Ocean. The study area, Elele is located within Latitude N 05 05-06' Longitude E $006^{\circ} 4-49^{\prime}$. Farming and petty business are major occupation of the Elele people. Palm oil and rubber are some of the useful economic crops cultivated in the area [22] [23]. Cassava is another major agricultural produce processed in the area. Elele has similar climatic condition with other parts of the Niger Delta which have been variously reported by authors [24]-[37].

\subsection{Selection Criteria for Subjects}

Inclusion Criteria: Post-menopausal subject within the age of 48 - 75 participated in this research are native and/or residing in Elele, Rivers state, Nigeriabetween 2016-2017. The subjects have not menstruated for not less than one year, hence showing evidence of cessation of menstrual period. 40 females within the age of 18 - 32 also participated in the study as control.

Exclusion Criteria: Adult females within the reproductive age that were pregnant and breastfeeding mothers. Also, individuals with known cases of disease conditions such as diabetes, hepatitis, tuberculosis, HIV 1\&2 and cardiovascular diseases.

\subsection{Blood Collection}

Blood was collected from each subject via the antecubital or dorsal vein following venipuncture approach. The blood samples from both test subjects and controls were dispensed into dipotassium EDTA tubes.

\subsection{Laboratory Analysis}

\subsubsection{Total White Blood Cell Estimation}

A 1:20 dilution of blood was made by adding $0.02 \mathrm{ml}$ of blood to $0.38 \mathrm{ml}$ of diluent (Turk's solution) in a glass tube. The content was then properly mixed for about 1 minute. By means of a Pasteur pipette, an improved Neubauer counting chamber covered with a cover slip was charged or filled with the suspension. Without delay, the leukocytes were counted using the $\times 10$ objective. The leukocytes in the $1 \mathrm{~mm}^{2}$ areas of the top and lower extremes were counted. The final leukocyte count per liter was calculated using the formula:

$$
\text { TWBC }=\frac{\text { No of cells counted }}{\text { Volume counted }(\mathrm{ml})} \times \text { Dilution } \times 10^{6}
$$

\subsubsection{Enumeration of CD4 Count Using Partec Cyflow}

Principle: The Partec Cyflow counter is a fully equipped portable/mobile flow cytometry system for the identification and the enumeration of the CD4 hel- 
per/inducer T-lymphocyte subset. Prepared stained sample from the tube flows through a capillary into the cuvette where the sheath fluid takes it with it. Because of the specific flow cuvette geometry, the sheath and sample current are speed up. The outcome is a very narrow laminar flowing sample stream does not mix up with the sheath fluid. The cells labeled with fluorescent coloring pass the measuring area one after the other. The cells are individually illuminated by the excitation light and the fluorescent light is measured and analyzed.

\section{Procedure:}

20- $\mu \mathrm{l}$ of whole blood was added into a Partec tube. $20 \mu \mathrm{l}$ of CD4 monoclonal antibody was added. It was gently mixed and incubated for 15 minutes at room temperature. $800 \mu \mathrm{l}$ of no lyse buffer was added and the tube mixed gently. It was analyzed on the Partec device. Sysmex CD4 easy count kit Lot No: 528576 antibody.

\subsection{Statistical Analysis}

Statistical analysis was carried out using Statistical Package for Social Sciences software version 20. Univariate (mean and standard deviation) and inferential (t-test) parameters were calculated. Significant variation between the test and control subjects was discerned at $\alpha<0.05$.

\section{Results and Discussion}

The total white blood cell and CD4 count among post-menopausal women in Elele River state is presented in Table 1. In the post-menopausal women (test subjects) and control, total white blood cell ranged from $2.7-7.9 \times 10^{9} / \mathrm{L}$ (Mean \pm Standard deviation $\left.5.46 \pm 1.64 \times 10^{9} / \mathrm{L}\right)$ and $4.9-10.5 \times 10^{9} / \mathrm{L}($ Mean \pm Standard deviation $\left.7.24 \pm 1.47 \times 10^{9} / \mathrm{L}\right)$ respectively. There was significant difference $(\mathrm{P}<0.001)$ among the test subjects and controls. The total white blood cell was significantly lower in the post-menopausal women when compared to the control. The values reported in this study is comparable to the work of Eledo et al. [4], that reported that total white blood count of $5.24 \pm 0.63 \times 10^{9} / \mathrm{L}$ and $7.23 \pm 1.04 \times 10^{9} / \mathrm{L}$ respectively in post-menopausal women and control respectively.

White blood cells are essential in protecting the human body against infections, pathogenic microbes and parasites. These cells are produced in the stem of the bone marrow and are composed of granulocytes (neutrophils, eosinophils,

Table 1. Total white blood cell and CD4 among post-menopausal women in Elele, River state, Nigeria.

\begin{tabular}{ccccc}
\hline \multirow{2}{*}{ Parameters } & \multicolumn{2}{c}{ Mean \pm Standard deviation } & \multirow{2}{*}{ t-value } & p-value \\
\cline { 2 - 3 } & Subjects $(\mathrm{n}=42)$ & Control $(\mathrm{n}=40)$ & & \\
\hline \multirow{2}{*}{ TWBC,$\times 10^{9} / \mathrm{L}$} & $5.46 \pm 1.64$ & $7.24 \pm 1.47$ & -5.151 & 0.0000 \\
& $(2.7-7.9)$ & $(4.9-10.5)$ & & \\
CD4, cell $/ \mu \mathrm{l}$ & $1265.19 \pm 459.56$ & $2159.53 \pm 400.02$ & -9.424 & 0.0000 \\
\hline
\end{tabular}

Data in parenthesis is range. 
and basophils) and non-granulocytes (lymphocytes and monocytes). Eledo et al. [4] have reported that monocytes decrease at menopause while other blood differentials such as neutrophils, eosinophils, basophil and lymphocytes are unaffected.

The CD4 cells counts ranged from $509-2120$ cells/ $\mu$ l (Mean \pm Standard deviation $1265.19 \pm 458.56 \mathrm{cells} / \mu \mathrm{l})$ and $1516-3151 \mathrm{cells} / \mu \mathrm{l}$ (Mean \pm Standard deviation $2159.53 \pm 400.02$ cells $/ \mu \mathrm{l})$ for test subjects and controls respectively. There was significant variation $(\mathrm{P}<0.001)$ among the test subjects and controls. Typically, T-cells are a subset of white blood cells that play an important role in the body's immune system. CD4 moleculeis a type of protein found on certain immune cells like T-cells, macrophages, and monocytes. The CD4 T-cells are considered as "helper" cells. This is due to their ability to trigger the body's response against infections. The lower CD4 counts in the menopausal compared to the control group in this study suggests a progressive weakness of T-cell mediated immune response linked to menopause. Gameiro et al. [38] reported that at menopause, there is an increase in pro-inflammatory serum markers (IL1, IL6, TNF-alpha) and response of the immune blood cells toward the cytokines, and a decrease in CD4 and B lymphocytes and cytotoxic activity of NK cells.

Figure 1 presents the total white blood cell counts among post-menopausal women according to age. The mean values were $4.9 \times 10^{9} / \mathrm{L}, 4.77 \times 10^{9} / \mathrm{L}, 5.75 \times$ $10^{9} / \mathrm{L}$ and $7.48 \times 10^{9} / \mathrm{L}$ for age grade of $41-50,51-60,61-70$ and $71-80$ years, respectively. There was significant difference $(\mathrm{P}=0.006)$ among the various age grade. Furthermore, Figure 2 presents CD4 cell counts among post-menopausal women according to age. The mean values were 650, 1115.81, 1394.92 and 1712.00 cells/ $\mu \mathrm{l}$ for age grades of $41-50,51-60,61-70$ and $71-80$ respectively.



Figure 1. Total white blood cell counts among post-menopausal women according to age. 


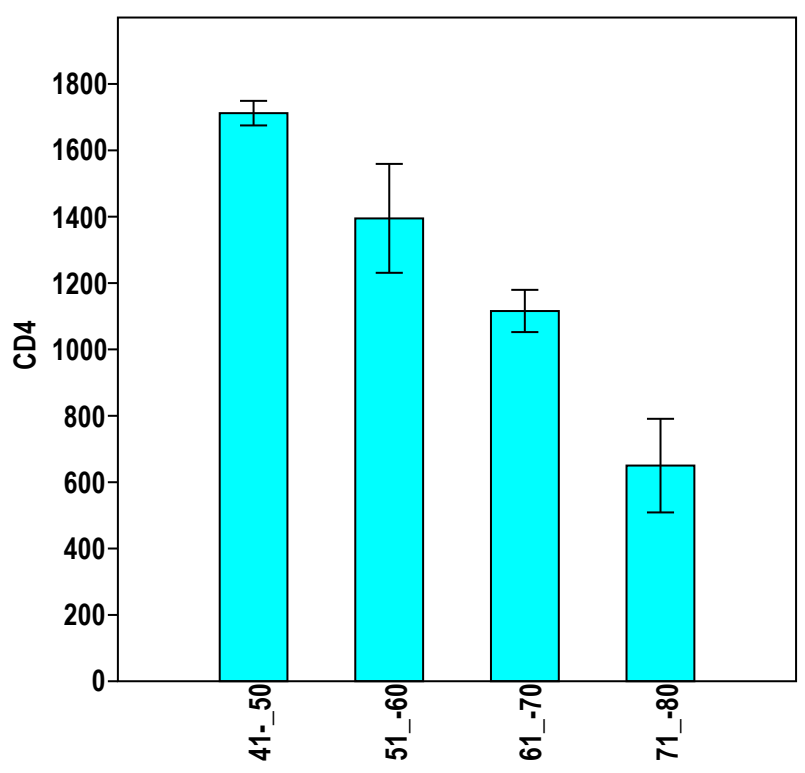

Figure 2. Total CD4 cell counts among post-menopausal women according to age.

Basically there was significant difference $(P=0.008)$ among the various age grade. This showed that after menopause the total white blood cell and CD4 count tend to decrease.

Previous study by Eledo et al. [4] has indicated that menopause reduces haemoglobin concentration, packed cell volume and platelets but increases erythrocyte sedimentation rate. This showed that menopause does not only affect CD4 and white blood cells of the woman body but also affects some other haematological parameters. Authors have reported that nutrition could also affect some haematological parameters. For instance, Padalia et al. [39] reported that poor nutrition resulted in vitamin B12 and folic acid deficiency; in old age this could cause haematological changes.

This reduction in total white blood cell and CD4 cells could be due to the effect of ageing. Also during ageing, the body may be predisposed to other health conditions that could lower the CD4 cell count of the body. Typically, authors have variously reported that ageing leads to a defect in immune system response and predisposes the body to multiple infections [4] [10] [11] [12] [13]. According to Sivro et al. [13], ageing decreases the ability of the body to fight against infections or foreign agents. Most of the studies suggest that in addition to age, estrogen deprivation may also contribute to changes in the immune response [38].

\section{Conclusion}

This study assessed total white blood cells and CD4 cell counts among post-menopausal women in Elele, River state, Nigeria. The findings of this study showed that after menopause, some immune system related parameters such as total white blood cells and CD4 cell counts decrease. This is evident in the sig- 
nificant reduction $(\mathrm{P}<0.001)$ in white blood cells and CD4 cell counts among post-menopausal women compared to young adults in reproductive age. The reduction in CD4 cells and total white blood cells may put women that have attained menopause at risk of multiple infections and other associated health conditions. Hence, at menopause, women should take caution in changes in their body physiology and chemistry to reduce the occurrence of avoidable infections.

\section{Ethical Consideration}

Permission was obtained from the ethics committees of the Medical Laboratory Science Department of Madonna University, Elele, Nigeria. Informed consent was obtained from the patients prior to sample collections.

\section{References}

[1] American Association for Clinical Chemistry (AACC) (2017) Menopause. https://labtestsonline.org/understanding/conditions/menopause

[2] Elder, J.A. and Thacker, H.L. (2016) Menopause. http://www.clevelandclinicmeded.com/medicalpubs/diseasemanagement/womenshealth/menopause/

[3] WebMD (2016) Your Health in Postmenopause. http://www.webmd.com/menopause/guide/health-after-menopause

[4] Eledo, B.O., Allagoa, D.O., Ihedioha, A.U., Dunga, K.C. and Izah, S.C. (2017) Evaluation of Some Haematological Parameters among Post-Menopausal Women in Bayelsa State, Nigeria: A Case Study of Patients Attending Federal Medical Centre, Yenagoa. American Journal of Laboratory Medicine, 2, 132-136.

[5] Dosi, R., Bhatt, N., Shah, P. and Patell, R. (2014) Cardiovascular Disease and Menopause. Journal of Clinical and Diagnostic Research, 8, 62-64.

[6] Nansseu, J.R.N., Moor, V.J.A., Nouaga, M.E.D., Zing-Awona, B., Tchanana, G., et al. (2016) Atherogenic Index of Plasma and Risk of Cardiovascular Disease among Cameroonian Postmenopausal Women. Lipids in Health and Disease, 15, 49. https://doi.org/10.1186/s12944-016-0222-7

[7] Achie, L.N., Olorunshola, K.V. and Mabrouk, M. (2011) A Study of Some Red Cell Indices in Menopausal Women in Zaria, Nigeria. Asian Journal of Medical Sciences, 3, 154-157.

[8] Moustafa, M.F., Ali, R.R., Elsaied, S.F. and Taha, S.A.M. (2015) Impact of Menopausal Symptoms on Quality of Life among Women's in Qena City. IOSR Journal of Nursing and Health Science, 4, 49-59.

[9] Akahoshi, M., Soda, M., Nakashima, E., Tominaga, T., Ichimaru, S., et al. (2002) The Effects of Body Mass Index on Age at Menopause. International Journal of $\mathrm{Ob}$ esity, 26, 961-968. https://doi.org/10.1038/sj.ijo.0802039

[10] Lages, C.S., Suffia, I., Velilla, P.A., Bin, H., Warshaw, G., et al. (2008) Functional Regulatory T Cells Accumulate in Aged Hosts and Promote Chronic Infectious Disease Reactivation. Journal of Immunology, 181, 1835-1848.

https://doi.org/10.4049/jimmunol.181.3.1835

[11] Gavazzi, G. and Krause, K.H. (2002) The Lancet Infectious Diseases-Ageing and Infection. The Lancet, 2, 659-666. https://doi.org/10.1016/S1473-3099(02)00437-1

[12] Pistilli, E.E., Siu, P.M. and Always, S.E. (2007) Interleukin-15 Responses to Aging 
and Unloading-Induced Skeletal Muscle Atrophy. American Journal of Physiology-Cell Physiology, 292, C1298-C1304. https://doi.org/10.1152/ajpcell.00496.2006

[13] Sivro, A., Lajoie, J., Kimani, J., Jaoko, W., Plummer, F.A., et al. (2013) Age and Menopause Affect the Expression of Specific Cytokines/Chemokines in Plasma and Cervical Lavage Samples from Female Sex Workers in Nairobi, Kenya. Immunity and Ageing, 10, 42. https://doi.org/10.1186/1742-4933-10-42

[14] Eledo, B.O., Dioka, C.E., Amilo, G.I., Ifeanyichukwu, M.O. and Onuoha, E.C. (2015) Evaluation of Some Haematological Parameters among Marijuana Smokers in Yenagoa, Nigeria. Journal of Biology, Agriculture and Healthcare, 5, 103-111.

[15] Eledo, B.O. (2014) Evaluation of Some Haematological and Immunological Parameters in Marijuana Smokers in Yenagoa, Bomadi and Okogbe, South-South, Nigeria. PhD Dissertation Submitted to Department of Medical Laboratory Sciences and Technology, Nnamdi Azikiwe University, Awka, 159 p.

[16] Igbeneghu, C. and Odaibo, A.B. (2013) Impact of Acute Malaria on Some Haematological Parameters in a Semi-Urban Community in Southwestern Nigeria. Acta Parasitologica Globalis, 4, 1-5.

[17] Eledo, B.O., Nwoga, M.I., Okamgba, O.C. and Izah, S.C. (2017) Assessment of Some Haemostatic Parameters among Diabetes Mellitus Patients in Bayelsa State: A Case Study at the Federal Medical Centre, Yenagoa. European Journal of Clinical and Biomedical Sciences, 3, 91-96.

[18] Eledo, B.O., Buseri, F.I. and Akhogba, A.O. (2015) Evaluation of Some Haematological Parameters among Pregnant Ijaw Women: An Indigenous West African Tribe. Journal of Health, Medicine and Nursing, 13, 10-17.

[19] Papadopol, V., Damian, O., Palamaru, I., Adam, C., Florescu, N. and Dămăceanu, D. (2001) Maternal Haematological and Biochemical Parameters and Pregnancy Outcome. The Journal of Preventive Medicine, 9, 27-33.

[20] Eledo, B.O., Igwe, R., Okamgba, O.C. and Izah, S.C. (2017) Effect of Exercise on Some Haemostatic Parameters among Students in a Tertiary Educational Institution in Nigeria. American Journal of Health Research, 5, 145-148. https://doi.org/10.11648/j.ajhr.20170505.15

[21] Cichocki, M. (2017) What Are CD4 T-Cells and Why Are They Important? https://www.verywell.com/what-are-cd4-t-cells-49354

[22] Ohimain, E.I., Daokoru-Olukole, C., Izah S.C. and Alaka, E.E. (2012) Assessment of the Quality of Crude Palm Oil Produced by Smallholder Processors in Rivers State, Nigeria. Nigerian Journal of Agriculture, Food and Environment, 8, 28-34.

[23] Ohimain, E.I., Daokoru-Olukole, C., Izah, S.C., Eke, R.A. and Okonkwo, A.C. (2012) Microbiology of Palm Oil Mill Effluents. Journal of Microbiology and Biotechnology Research, 2, 852-857.

[24] Ben-Eledo, V.N., Kigigha, L.T., Izah, S.C. and Eledo, B.O. (2017) Water Quality Assessment of Epie Creek in Yenagoa Metropolis, Bayelsa State, Nigeria. Archives of Current Research International, 8, 1-24. https://doi.org/10.9734/ACRI/2017/34504

[25] Ben-Eledo, V.N., Kigigha, L.T., Izah, S.C. and Eledo, B.O. (2017) Bacteriological Quality Assessment of Epie Creek, Niger Delta Region of Nigeria. International Journal of Ecotoxicology and Ecobiology, 2, 102-108.

[26] Seiyaboh, E.I., Izah, S.C. and Bokolo, J.E. (2017) Bacteriological Quality of Water from River Nun at Amassoma Axises, Niger Delta, Nigeria. ASIO Journal of Microbiology, Food Science \& Biotechnological Innovations, 3, 22-26.

[27] Seiyaboh, E.I., Izah, S.C. and Oweibi, S. (2017) Physico-Chemical Characteristics of 
Sediment from Sagbama Creek, Nigeria. Biotechnological Research, 3, 25-28.

[28] Seiyaboh, E.I., Izah, S.C. and Oweibi, S. (2017) Assessment of Water Quality from Sagbama Creek, Niger Delta, Nigeria. Biotechnological Research, 3, 20-24.

[29] Seiyaboh, E.I., Inyang, I.R. and Izah, S.C. (2016) Seasonal Variation of Physico-Chemical Quality of Sediment from Ikoli Creek, Niger Delta. International Journal of Innovation in Environmental Studies Research, 4, 29-34.

[30] Seiyaboh, E.I., Inyang, I.R. and Izah, S.C. (2016) Spatial Variation in Physico-Chemical Characteristics of Sediment from Epie Creek, Bayelsa State, Nigeria. Greener Journal of Environmental Management and Public Safety, 5, 100-105. https://doi.org/10.15580/GJEMPS.2016.5.121616214

[31] Seiyaboh, E.I. and Izah, S.C. (2017) Bacteriological Assessment of a Tidal Creek Receiving Slaughterhouse Wastes in Bayelsa State, Nigeria. Journal of Advances in Biology and Biotechnology, 14, 1-7. https://doi.org/10.9734/JABB/2017/34593

[32] Seiyaboh, E.I. and Izah, S.C. (2017) Review of Impact of Anthropogenic Activities in Surface Water Resources in the Niger Delta region of Nigeria: A Case of Bayelsa State. International Journal of Ecotoxicology and Ecobiology, 2, 61-73.

[33] Ogamba, E.N., Ebere, N. and Izah, S.C. (2017) Heavy Metal Concentration in Water, Sediment and Tissues of Eichhornia Crassipes from Kolo Creek, Niger Delta. Greener Journal of Environmental Management and Public Safety, 6, 1-5. https://doi.org/10.15580/GJEMPS.2017.1.020817018

[34] Ogamba, E.N., Ebere, N. and Izah, S.C. (2017) Levels of Lead and Cadmium in the Bone and Muscle Tissues of Oreochromis niloticus and Clarias camerunensis. EC Nutrition, 7, 117-123.

[35] Ogamba, E.N., Izah, S.C. and Oribu, T. (2015) Water Quality and Proximate Analysis of Eichhornia crassipes from River Nun, Amassoma Axis, Nigeria. Research Journal of Phytomedicine, 1, 43-48.

[36] Ogamba, E.N., Izah, S.C. and Toikumo, B.P. (2015) Water Quality and Levels of Lead and Mercury in Eichhornia crassipes from a Tidal Creek Receiving Abattoir Effluent, in the Niger Delta, Nigeria. Continental Journal of Environmental Science, 9, 13-25.

[37] Ogamba, E.N., Seiyaboh, E.I., Izah, S.C., Ogbugo, I. and Demedongha, F.K. (2015) Water Quality, Phytochemistry and Proximate Constituents of Eichhornia crassipes from Kolo Creek, Niger Delta, Nigeria. International Journal of Applied Research and Technology, 4, 77-84.

[38] Gameiro, M., Romão, F. and Castelo-Branco, C. (2010) Menopause and Aging: Changes in the Immune System-A Review. Maturitas, 67, 316-320. https://doi.org/10.1016/j.maturitas.2010.08.003

[39] Padalia, M.S., Trivedi, R.S., Panchal, P. and Jani, H. (2014) Effect of Aging on Various Haematological Parameters. International Journal of Biomedical and Advance Research, 5, 494-495. https://doi.org/10.7439/ijbar.v5i10.901 